\title{
Immunochemistry and electron microscopy of head and neck rhabdomyoma
}

\author{
T R HELLIWELL, * M C J SISSONS, * P J STONEY, † M T ASHWORTH* \\ From the Departments of *Pathology and †Otorhinolaryngology, University of Liverpool, Liverpool
}

SUMMARY Rhabdomyomas are rare benign tumours originating in skeletal or cardiac muscle. Extracardiac tumours are usually situated in the head and neck. Four cases are presented, three arising in the larynx and the other in the cervical region. All four cases were studied by light and electron microscopy, and in three immunohistochemical staining for myoglobin, desmin, and vimentin was carried out to study the diagnostic features of the lesions and their histogenesis.

Extracardiac rhabdomyomas are rare tumours that usually affect the head and neck and occasionally the vulva and the vagina. Cases can usually be categorised histologically as adult and fetal types ${ }^{1}$ though a case with features of both types has recently been described. ${ }^{2}$ The adult type is more common and occurs mainly in the head and neck of adult men. Characteristically it has a well defined margin and is composed of sheets of closely packed large round cells with granular eosinophilic cytoplasm, some containing cross striations. Fetal type rhabdomyomas were first described in detail by Dehner et al. ${ }^{3}$ They are usually poorly defined and are composed predominantly of primitive mesenchymal cells with few mature muscle cells. Two subgroups are recognised as cellular and myxoid variants. ${ }^{4}$ Fetal cellular rhabomyomas are seen at many sites but myxoid rhabdomyomas are commonly found in the vulvas or vaginas of middle aged women. All types of rhabdomyoma behave similarly in that they are usually solitary, slowly growing lesions for which surgical excision is curative. Only four locally recurrent tumours have been described to our knowledge. ${ }^{56}$

Of the 115 extracardiac rhabdomyomas reported, 87 have occurred in the head and neck of which 15 were in the larynx (table). Cases described before 1980 are listed by Di Saint Agnese and Knowles ${ }^{4}$ and by Corio and Lewis, ${ }^{5}$ and have not been given separate references. Ten cases of multifocal lesions have been described..$^{7-12}$ Adult type rhabdomyomas are three times more likely to occur in men than women and present at a mean age of 55 years. Half the fetal rhabdomyomas occur in children under the age of 3 years and they affect boys and girls equally.

The light and electron microscopic appearances of

Accepted for publication 5 May 1988 rhabdomyomas have been well described (table), but immunohistochemistry has only been carried out in four cases, three using antisera against myoglobin ${ }^{21314}$ and one against desmin. ${ }^{15}$ We present four cases (three adult type and one fetal myxoid type) of rhabdomyoma in which light and electron microscopy were carried out. In three cases the immunohistochemical phenotype of the cells was investigated using antisera reacting to desmin, vimentin, and myoglobin to define their diagnostic features and to study aspects of their histogenesis.

\section{Material and methods}

All tissue was fixed in buffered $10 \%$ formaldehyde and embedded in paraffin wax. Tissue sections were stained with haematoxylin and eosin and with phosphotungstic acid haematoxylin (PTAH), periodic acid Schiff (PAS), Masson's trichrome and Van Gieson methods. Immunohistochemical staining was carried

Table Details of 115 reported rhabdomyomas

\begin{tabular}{|c|c|c|c|c|}
\hline $\begin{array}{l}\text { Site and type } \\
\text { of tumour }\end{array}$ & $\begin{array}{l}\text { No of } \\
\text { tumours }\end{array}$ & $\begin{array}{l}\text { Mean age } \\
\text { of patients } \\
\text { (years) }\end{array}$ & $\begin{array}{l}\text { No of } \\
\text { women }\end{array}$ & $\begin{array}{l}\text { No of } \\
\text { men }\end{array}$ \\
\hline $\begin{array}{l}\text { Larynx: } \\
\text { Adult } \\
\text { Fetal cellular }^{42324} \\
\text { Fetal myxoid }^{425}\end{array}$ & $\begin{array}{l}9 \\
3 \\
3\end{array}$ & $\begin{array}{l}58 \\
37 \\
67\end{array}$ & $\begin{array}{l}2 \\
1 \\
2\end{array}$ & $\begin{array}{l}7 \\
2 \\
1\end{array}$ \\
\hline $\begin{array}{l}\text { Other parts of head an } \\
\text { Adult } \\
\text { Fetal cellular }_{13-15} 26-33 \\
\text { Fetal myxoid } \\
\text { Other }^{43537}\end{array}$ & $\begin{array}{l}\text { neck: } \\
51 \\
10 \\
8 \\
3\end{array}$ & $\begin{array}{l}56 \\
31 \\
15 \\
<1\end{array}$ & $\begin{array}{r}12 \\
4 \\
1 \\
1\end{array}$ & $\begin{array}{r}39 \\
6 \\
7 \\
1\end{array}$ \\
\hline $\begin{array}{l}\text { Other sites: } \\
\text { Adult } \\
\text { Fetal cellular } \\
\text { Fetal myxoid } 113338 \\
\text { Other }^{2439}\end{array}$ & $\begin{array}{r}2 \\
6 \\
16 \\
4\end{array}$ & $\begin{array}{r}30 \\
26 \\
30 \\
8\end{array}$ & $\begin{array}{r}1 \\
4 \\
13 \\
3\end{array}$ & $\begin{array}{l}1 \\
2 \\
3 \\
1\end{array}$ \\
\hline
\end{tabular}




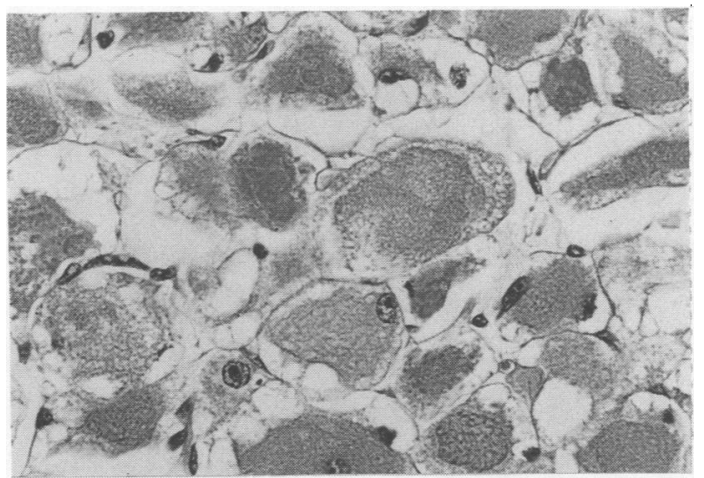

Fig 1 Case 1: adult rhabdomyoma of larynx composed of polygonal cells with granular cytoplasm. (Haematoxylin and eosin.)

out in cases 2,3 , and 4 by the peroxidase antiperoxidase method using a polyclonal antibody to myoglobin (DAKO A324), and monoclonal antibodies to vimentin (DAKO M725), and desmin (DAKO M724). For electron microscopic examination, tissue was deparaffinised in xylene, rehydrated, and fixed in osmium tetroxide for one hour before being embedded in $\mathrm{E}$ mix resin. Sections were stained with uranyl acetate and lead citrate.

\section{Case reports}

\section{CASE 1}

A 52 year old man presented with a six month history of hoarseness and laryngoscopy showed mild swelling of the left vocal cord. He was followed up for 24 months during which time the swelling increased. A lateral pharyngotomy was carried out at which a smooth, lobulated, well defined brown mass $1.5 \mathrm{~cm}$ in diameter was removed. Histologically the tumour was composed of closely packed, large, round cells with vacuolated or granular eosinophilic cytoplasm (fig 1).

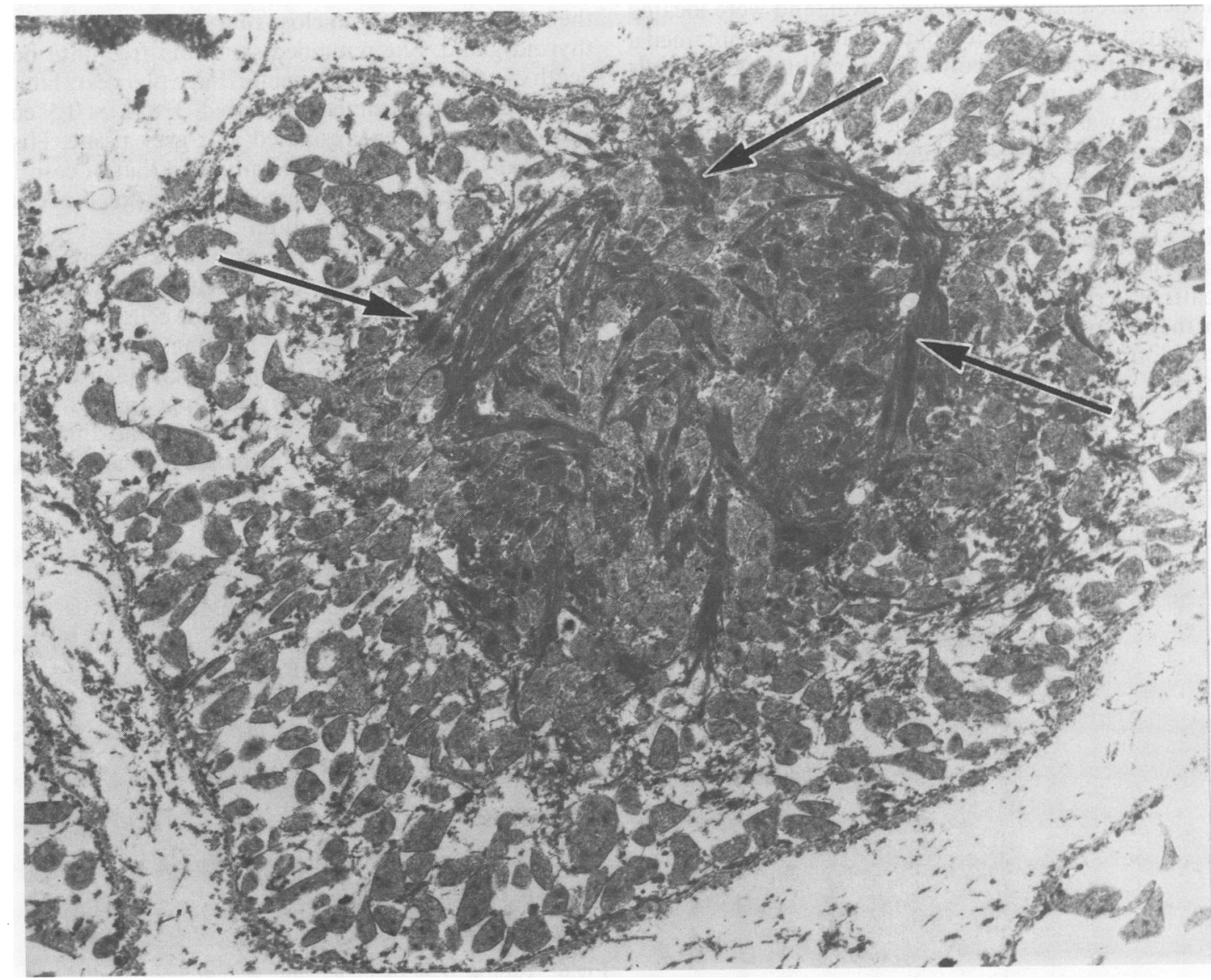

Fig 2 Case 1: electron micrograph of adult type rhabomyoma. Cytoplasmic fibrils arranged haphazardly are present, some containing electron dense areas resembling $Z$ line material (arrows). 


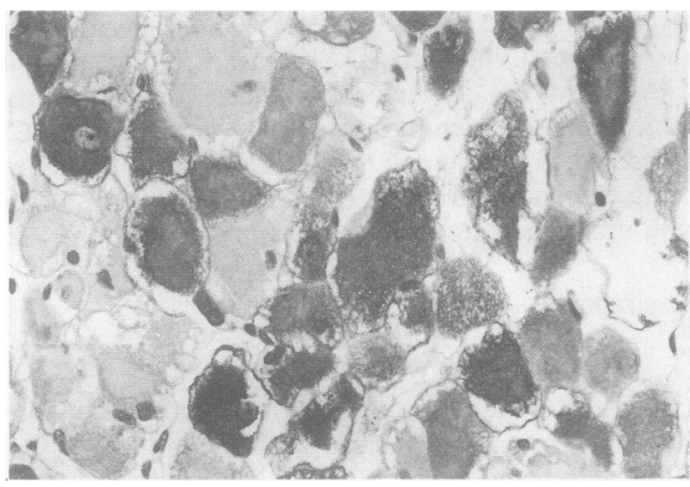

Fig 3 Case 2: adult rhabdomyoma stained for myoglobin. (Immunoperoxidase.)

Cross striations, identified most clearly with the PTAH and trichrome strains were occasionally seen, and most cells showed granular PAS staining. The nuclei were uniform, round or oval, and were located at the periphery or centre of the cell; many contained a single prominent nucleolus. Some multinucleated cells were seen but no mitoses. No immunohistochemical staining was performed but electron microscopic examination showed abundant cytoplasmic fibrils arranged either in parallel or in a haphazard manner. Some fibre bundles showed focal electron densities (fig 2) resembling $\mathrm{Z}$ line material. Numerous mitochondria, abundant endoplasmic reticulum, and scattered granules of glycogen were seen, particularly in the centres of the cells. A diagnosis of adult type rhabdomyoma was made, and the patient was well 18 months after operation.

\section{CASE 2}

A 76 year old woman presented with a four month history of hoarseness and a two week history of a lump in the right side of the neck. At laryngoscopy a polyp

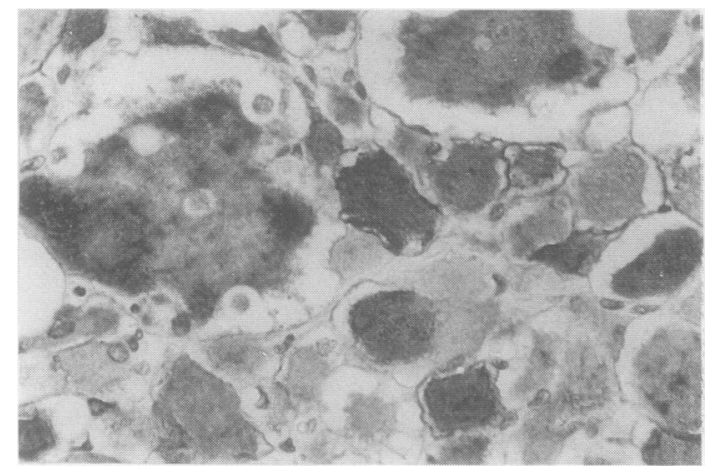

Fig 4 Case 2: adult rhabdomyoma showing cytoplasmic staining for desmin. (Immunoperoxidase.)

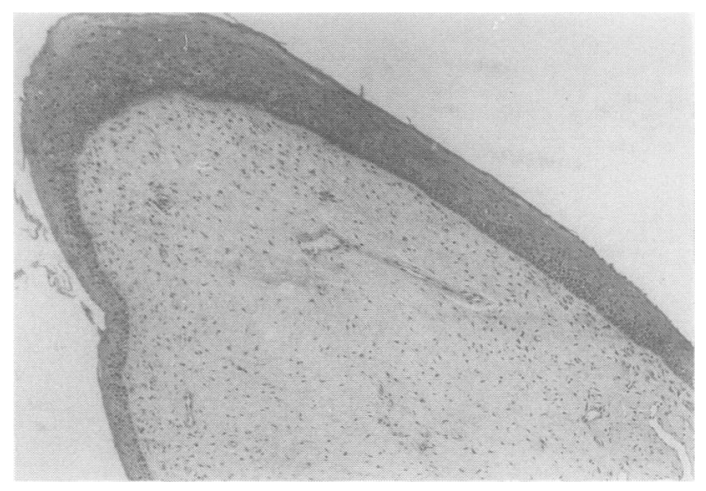

Fig 5 Case 4: fetal rhabdomyoma showing the polypoid nature of the lesion and its scanty cellularity. (Haematoxylin and eosin.)

on the left false cord was deroofed, and at a second operation a mass $3 \mathrm{~cm}$ in diameter was excised from the right cervical region close to the upper pole of the thyroid gland. She remained symptom free until her death of an intracerebral haemorrhage two years later.

The excised specimen measured $3 \times 2 \times 0.5 \mathrm{~cm}$ and consisted of encapsulated soft grey tissue. Histologically the tumour was identical to that of case 1 . The lesion on the left false cord was a mucous cyst lined with columnar epithelium.

Immunohistochemical staining of the cervical lesion showed diffuse cytoplasmic positivity for myoglobin (fig 3) and desmin (fig 4) in most of the cells with a few pale staining cells. Vimentin staining was negative. Ultrastructurally the appearances were identical to those of case 1. The histological appearances were those of an adult type rhabdomyoma, and this was supported by the immunohistochemical and ultrastructural findings.

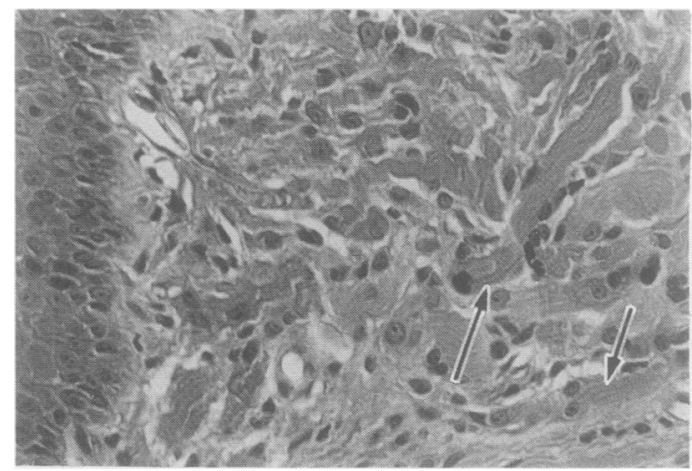

Fig 6 Case 4: fetal rhabdomyoma with groups of cells containing cross-striations (arrows). (Haematoxylin and eosin.) 


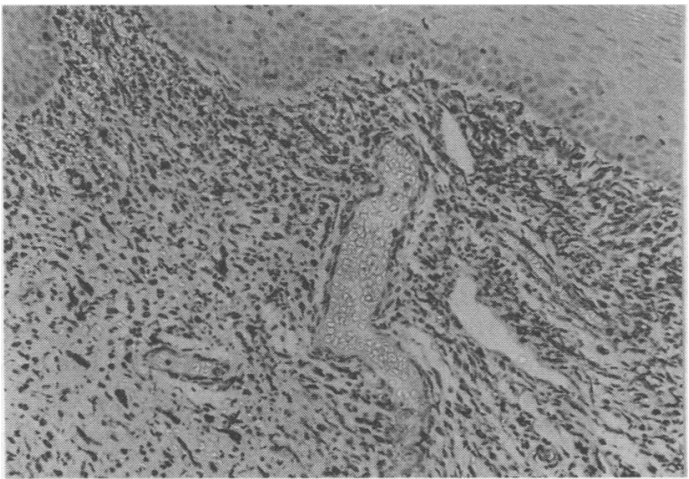

Fig 7 Case 4: fetal rhabdomyoma stained for vimentin. (Immunoperoxidase.)

\section{CASE 3}

A 66 year old man presented with an eight year history of hoarseness. Three years earlier his right vocal cord had been noted to be thickened, but this was stripped and histological examination showed only congestion and fibrosis. Laryngoscopy now showed a smooth swelling $3 \mathrm{~cm}$ in diameter arising just below the right vocal cord. It was encapsulated, soft, and grey, and histologically and ultrastructurally the appearances were identical to the adult rhabdomyomas seen in cases 1 and 2. Immunohistochemical staining was also similar with the component cells positive for myoglobin and desmin, and negative for vimentin.

\section{CASE 4}

A 44 year old man with a six month history of sore throat was found to have a polyp $0.5 \mathrm{~cm}$ in diameter at the posterior commissure of the vocal cords. The surgical specimen was brown, soft, and irregularly shaped. Microscopically the tissue consisted of intact and normal surface epithelium covering an ill defined

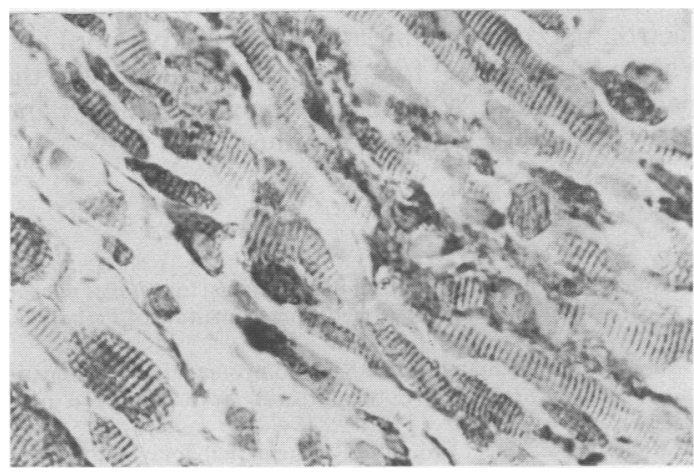

Fig 8 Case 4: fetal rhabdomyoma stained for desmin showing strong cytoplasmic staining of striated cells. (Immunoperoxidase.)

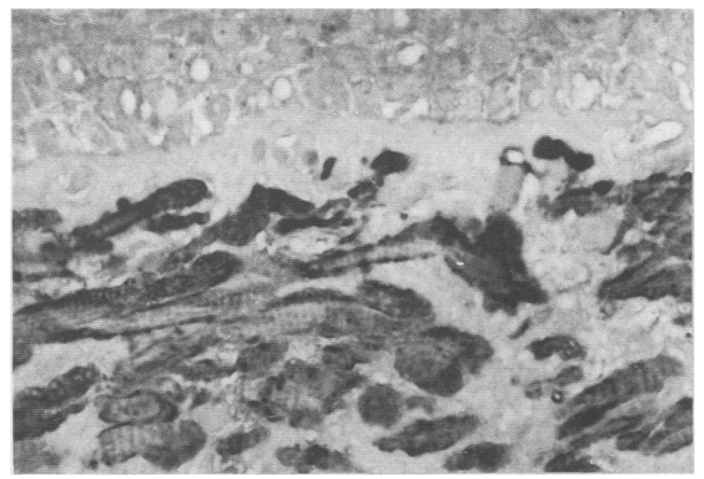

Fig 9 Case 4: fetal rhabdomyoma showing striated cells stained for myoglobin. (Immunoperoxidase.)

tumour composed of scanty cells in a myxoid stroma (fig 5). The tumour cells were predominantly spindleshaped cells varying in diameter, with oval nuclei and scanty cytoplasm, arranged in a disorganised manner but more closely aggregated in the superficial lamina propria. There were also small subepithelial groups of larger round or elongated cells with peripheral nuclei and abundant eosinophilic cytoplasm containing cross-striations (fig 6). No mitoses were seen. Immunohistochemical staining showed diffuse cytoplasmic positivity for desmin and vimentin in the non-striated cells (fig 7) but not for myoglobin. The striated cells stained strongly for desmin (fig 8) and myoglobin (fig 9), but not for vimentin. Electron microscopic examination of the undifferentiated spindle cells showed central nuclei, scanty organelles, and no glycogen. A few cells contained loosely arranged filaments in the cytoplasm. The striated cells contained peripheral nuclei and myofibrils arranged in

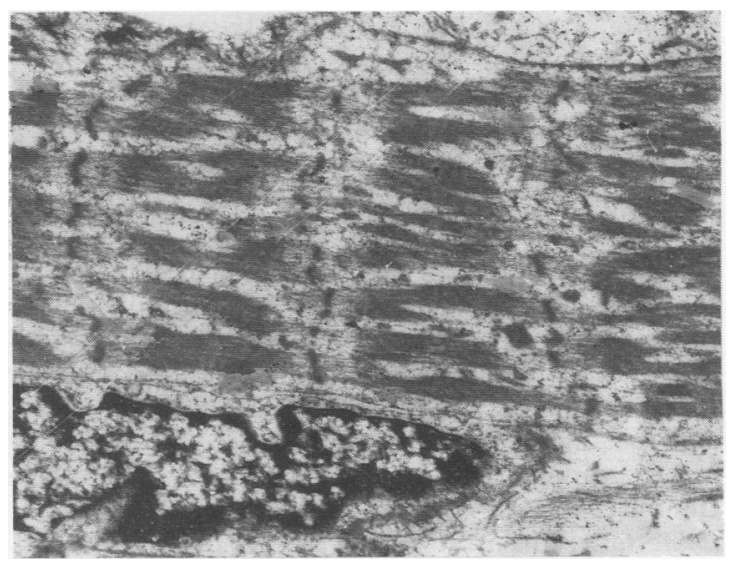

Fig 10 Case 4: electron micrograph of a fetal rhabdomyoma showing a cell containing myofibrils arranged in parallel with formation of $Z$ lines. 
parallel with prominent $A$ and $I$ bands and $Z$ lines (fig 10). A diagnosis of a fetal myxoid rhabdomyoma was made.

\section{Discussion}

These four cases are similar to previously reported cases in their clinical features and light and electron microscopic appearances. The clinical features are similar to those of other polypoid lesions encountered in the head and neck. Cervical lesions may resemble enlarged lymph nodes so that rhabdomyoma should enter the differential diagnosis of both solitary and multifocal lesions in that part of the body. The diagnosis is usually only made when biopsy specimens are examined histologically. The light microscopic features are usually characteristic, but if small endoscopic or needle biopsy specimens are taken additional techniques may be required before the diagnosis is confirmed. Electron microscopy is time consuming, but despite the artefacts inevitably present in formalin fixed tissue it may be useful if thick and thin filaments with dense bodies can be identified. As these are likely to be present in only a few cells in all types of rhabdomyoma, sampling difficulties may make diagnosis difficult. The principal differential diagnoses for adult rhabdomyoma are benign granular cell tumour and oncocytic salivary adenoma.

Though trichrome and mucin stains will enable a distinction to be made in most instances, the use of immunohistochemistry to identify myoglobin or desmin, or both, in adult rhabdomyomas should be helpful. Benign granular cell tumours stain positively for $\mathrm{S}-100$ protein, ${ }^{16}$ but not for desmin or myoglobin. Fetal myxoid rhabdomyomas may be confused with simple polps of the vocal cords, and again careful routine microscopic examination supplemented by staining for desmin should enable the diagnosis to be made. Myoglobin is a less useful marker as there are likely to be only a few positively staining cells. Vimentin is a non-specific mesenchymal marker and is positive in simple polyps. Fetal cellular rhabdomyomata are more likely to be confused with malignant neoplasms, particularly embryonal rhabdomyosarcoma. Qualitative identification of markers of skeletal muscle differentiation will not help in making this distinction and careful light microscopic examination is essential. The fetal cellular rhabdomyoma tends to be fairly well circumscribed, superficially located, and characterised by increasing cellular differentiation towards the periphery of the tumour. Mitotic figures and areas of necrosis are rare.

Desmin is the most reliable marker for cells expressing skeletal or smooth muscle differentiation as it is present in both primitive and mature cells. ${ }^{17}$ Vimentin is present in primitive but not mature skeletal muscle ${ }^{18}$ and myoglobin is present in much greater quantity in mature than in fetal muscle. ${ }^{19}$ Our study of rhabdomyomas supports these findings in normal muscle. The fetal rhabdomyoma shows both desmin and vimentin in the primitive cells, and desmin and myoglobin in the more mature striated cells. The adult rhabdomyoma is composed of comparatively mature cells that stain for desmin and myoglobin, but not for vimentin. The immunohistochemical findings are paralleled by the ultrastructural appearances, with greater maturity being shown by increased numbers and organisation of cytoplasmic filaments.

In adults, both fetal type and adult type rhabdomyomas behave like benign neoplasms, but some authors have suggested that the fetal type of rhabdomyoma in children may be hamartomatous, ${ }^{312}$ and it may be associated with the naevoid basal cell carcinoma syndrome." The likely rate of growth is not clear, recurrent tumours being clinically evident between 9 months and 10 years after the initial operation, and second tumours being detected between four and 10 years later. The low incidence and slow rate of growth suggest that follow up is not required unless symptoms persist or recur.

Since this paper was accepted for publication, Eusebi et al have published a similar immunocytochemical study of two adult rhabdomyomas (of tongue and pharynx) and two fetal rhabdomyomas (of tongue and larynx). ${ }^{40}$ They reported patterns of staining for desmin, vimentin, and myoglobin which are identical with those in our cases and, in addition, observed fetal myosin in all four lesions. Their findings substantiate our comments on the phenotypic resemblance of fetal rhabdomyomas to fetal muscle and suggest that adult rhabdomyomas resemble neonatal muscle.

We thank Professor PH Stell and Mr N Bark-Jones for permission to report their cases, the staff of the electron microscopy unit at the Royal Liverpool and Walton Hospitals for the preparation of the specimens, Mr A Williams for the photography, and Miss C Youd for typing the manuscript.

\section{References}

1 Stout AP, Lattes R. Tumours of the soft tissue. In: Atlas of tumour pathology. Washington: Armed Forces Institute of Pathology, 1967.

2 Whitten RO, Benjamin DR. Rhabdomyoma of the retroperitoneum. A report of a tumour with both adult and fetal characteristics. Cancer 1987;59:818-24.

3 Dehner LP, Enzinger FM, Font RL. Fetal rhabdomyoma. Cancer 1972;30:160-6.

4 Di Sant Agnese PA, Knowles DM. Extracardiac rhabdomyoma: a clinicopathologic study and review of the literature. Cancer 1980;46:780-9. 
5 Corio RL, Lewis DM. Intraoral rhabdomyoma. Oral Surgery 1979;48:525-31.

6 Andersen CB, Elling F. Adult rhabdomyoma of the oropharynx recurring three times within thirty-five years. Acta Pathol Microbiol Immunol Scand (A) 1986;94:281-4.

7 Schlosnagle DC, Kratochvil FJ, Weathers DR, McConnel FMS, Campbell WG. Intraoral multifocal adult rhabdomyoma. Arch Pathol Lab Med 1983;107:638-42.

8 Gardner DG, Corio RL. Multifocal adult rhabdomyoma. Oral Surg Oral Med Oral Pathol 1983;56:76-8.

9 Neville BW, McConnel FMS. Multifocal adult rhabdomyoma. Arch Otolaryngol 1981;107:175-8.

10 Scrivner D, Meyer JS. Multifocal recurrent adult rhabdomyoma. Cancer 1980;46:790-5.

11 Dahl I, Angervall L, Save-Soderbergh J. Foetal rhabdomyoma. Case report of a patient with two tumours. Acta Pathol Microbiol Scand (A) 1976;84:107-12.

12 Goldman RL. Multicentric benign rhabdomyoma of skeletal muscle. Cancer 1963;16:1609-13.

13 Warner TFCS, Goell W, Sunharadas M, Falk VS. Adult rhabdomyoma. Ultrastructure and immunocytochemistry. Acta Pathol Lab Med 1981;105:608-11.

14 Cerasoli PT, Pirodda A, Caliceti U. Rabdomioma di tipo adulto: Presentazione di un caso clinico e della regions foringo-laringea studio immunoistochinico. Acta Otorhinolaryngol Ital 1985;5:175-83.

15 Lehtonen E, Asibainen U, Badley RA. Rhabdomyoma. Ultrastructural features and distribution of desmin, muscle type of intermediate filament protein. Acta Pathol Microbiol Immunol Scand (A) 1982;90:125-9.

16 Stefansson K, Wollman RL. S-100 protein in granular cell tumours (granular cell myoblastoma) Cancer 1982;49:1834-8.

17 Holtzer H, Bennett GS, Tapscott SJ, Croop JM, Toyama Y. Intermediate-size filaments: changes in synthesis and distribution in cells of myogenic and neurogenic lineages. $C$ Sp $H$ Symp Quant Biol 1981;46:317-29.

18 Gown AM, Vogel AM. Monoclonal antibodies to human intermediate filaments. Am J Pathol 1984;114:309-21.

19 Kagen LJ, Christian CL. Immunologic measurements of myoglobin in human adult and fetal skeletal muscle. Am J Physiol 1966;211:656-60.

20 Boedts D, Mestdagh J. Adult rhabdomyoma of the larynx. Arch Otolaryngol 1979;224:221-9.

21 Kleinsasser O, Glanz H. Myogenic tumours of the larynx. Arch Otolaryngol 1979;225:107-19.

22 Van de Eeckhaut J, Fievez C, Remacle M, Coffyn MB, Marbaix E. Rhabdomyome adulte du larynx. A propos d'un cas. Ann OtoLaryngol 1983;100:151-3.

23 Granich MS, Pilch BZ, Nadol JB, Dickersin R. Fetal rhabdomyoma of the larynx. Arch Otolaryngol 1983;109:821-6.
24 Modin B, Spring S. Rhabdomyoma of the larynx. Laryngoscope 1982;92:580-2.

25 Rosenman D, Gertner R, Fradis M, Podoshin L, Misslevitsch, Boss JH. Rhabdomyoma of the larynx. J Laryngol Otol 1986;100:607-10.

26 Silseth C, Veress B, Bergstrom B. A case of adult rhabdomyoma in the tonsillar region. Acta Pathol Microbiol Immunol Scand (A) 1982;90:1-4.

27 Reid CO, Smith CJ. Rhabdomyoma of the floor of the mouth: a new case and a review of recently reported intra-oral rhabdomyomas. Br J Oral Maxillofac Surg 1985;23:284-91.

28 Weitzner S, Lockley MW, Lockard VG. Adult rhabdomyoma of soft palate. Oral Surg Oral Med Oral Path 1979;47:70-3.

29 Tanner NSB, Carter RL, Clifford P. Pharyngeal rhabdomyoma: an unusual presentation. J Laryngol Otol 1978;92:1029-36.

30 Milier R, Kurtz SM, Powers JM. Mediastinal rhabdomyoma. Cancer 1978;42:1983-8.

31 Krespi YP, Som PM, Shugar JMA. Rhabdomyomas: a rare cause of unilateral proptosis. Mt Sinai J Med 1979;46:392-5.

32 Lee YS, Tang CK. Oncocytic change in adult rhabdomyoma. Ann Acad Med Singapore 1986;15:85-6.

33 Marquart KH. Intracristale lineare Einschlusse in Mitochondrien menschlicher Rhabdomyomzellen, Virchows Arch Pathol Anat 1978;378:133-41.

34 Konrad EA, Meister P, Hubner G. Extracardiac rhabdomyomas: report of different types with light microscopic and ultrastructural studies. Cancer 1982;49:898-907.

35 Simha M, Doctor V, Dalai S, Manghani DK, Dastur DK. Postauricular fetal rhabdomyoma: light and electron microscopic study. Hum Pathol 1982;13:637-47.

36 Walter P, Guerbaoui M. Rhabdomyome foetal. Etude histologique et ultrastructural d'une nouvelle observation. Virchows Arch, Pathol Anat 1976;371:59-67.

37 Gardner DG, Corio RL. Fetal rhabdomyoma of the tongue with a discussion of the two histolgic variants of this tumour. Oral Surgery 1983;56:293-300.

38 Gee DC, Finckh ES. Benign vaginal rhabdomyoma. Pathology 1977;9:263-7.

39 Chabrel CM, Beilby JOV. Vaginal rhabdomyoma. Histopathology 1980;4:645-51.

40 Eusebi V, Ceccarelli C, Daniele E, Collina G, Viale G, Mancini AM. Extracardiac rhabdomyoma: an immunocytochemical study and review of the literature. Applied Pathology 1988;6:197-207.

Requests for reprints to: Dr T R Helliwell, Department of Pathology, University of Liverpool, PO Box 147, Liverpool L69 3BX, England. 